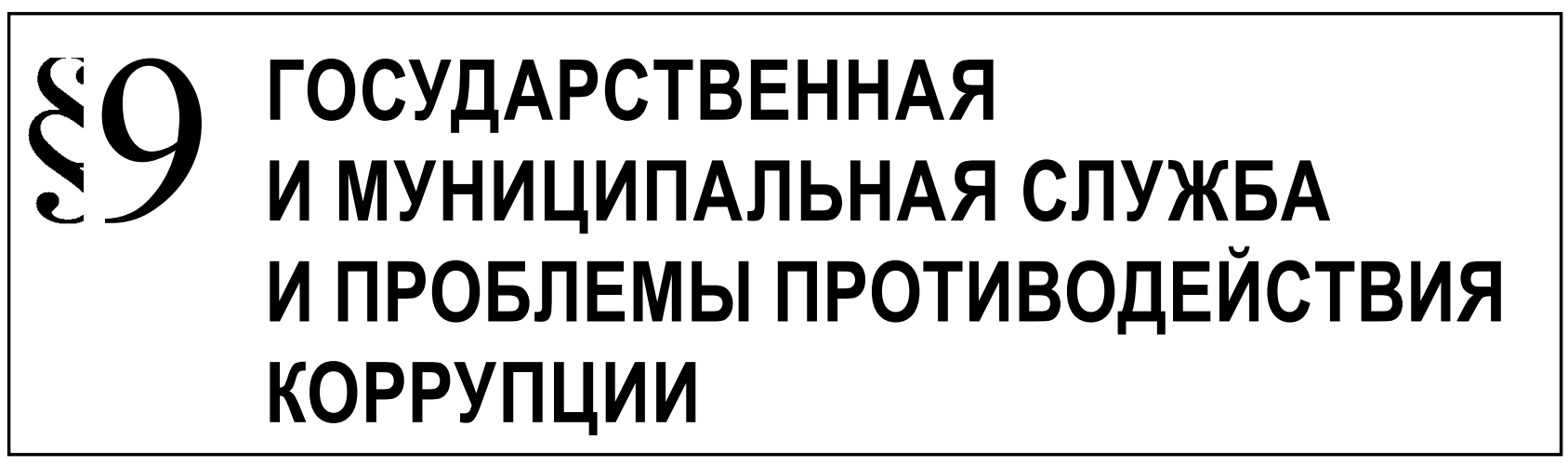

Агеев В.Н.

\title{
КОМИССИЯ ПО КООРДИНАЦИИ РАБОТЫ ПО ПРОТИВОДЕЙСТВИЮ КОРРУПЦИИ В СУБЪЕКТЕ РОССИЙСКОЙ ФЕДЕРАЦИИ: ОБЩИЕ ПОЛОЖЕНИЯ
}

\begin{abstract}
Аннотация. Предметом настоящего исследования является Типовое положение о комиссии по координации работы по противодействию коррупции в субъекте Российской Федерации, утвержденное Указом Президента Российской Федерации от 15 июля 2015 года № 364 «О мерах по совершенствованию организации деятельности в области противодействия коррупции». В статье рассматриваются вопросы правового положения Комиссии по координации работы по противодействию коррупции в субъекте Российской Федерации, правовая основа её деятельности, назначение Комиссии, анализируется опыт образования такой Комиссии в Республике Татарстан. Основу исследования составил Указ Президента Российской Федерации om 15 июля 2015 года № 364 «О мерах по совершенствованию организации деятельности в области противодействия коррупции», а также нормативные правовые акты как федерального, так и регионального уровней. В работе использовались как общенаучные, так и специальные методы исследования - формально-юридический, сравнительно-правовой, метод толкования правовых норм. Новизна исследования заключается в отсутствии исследований по данной проблематике. Автор приходит к следующему выводу: создание комиссий по координации работы по противодействию коррупции в субъекте Российской Федерации служит стандартизации государственной политики по противодействию коррупции в субъектах Российской Федерации и установливает определённую вертикаль в системе противодействия коррупции на всей территории России.
\end{abstract}

Ключевые слова: коррупция, антикоррупционная политика, противодействие коррупции, государственная политика, государственная служба, региональная антикоррупционная политика, антикорруционное законодательство, правовая основа деятельности, конфликт интересов, урегулирование конфликта интересов.

Abstract. The research subject is the Model provisions on the corruption prevention coordination Commission in the subordinate entity of the Russian Federation established by the Presidential Decree of 15 July 2015 No 364 "On the measures of corruption prevention improvement". The paper considers the issues of legal status of the corruption prevention coordination Commission, the legal grounds of its activities and its purpose, analyzes the experience of this Commission in the Republic of Tatarstan. The research is based on the Presidential Decree of 15 July 2015 No 364 "On the measures of corruption prevention improvement", and statutory instruments of the federal and local level. The author applies general scientific and specific research methods: formal-logical, comparative-legal and the method of legal provisions interpretation. The scientific novelty of the study is determined by the lack of scientific works in this field. The author concludes that the formation of corruption prevention cooperation commissions in the entities of the Russian Federation promotes the standardization of the state policy of corruption prevention in the entities of the Russian Federation and establishes a vertical in the system of corruption combating in Russia.

Key words: conflict of interest management, conflict of interest, legal ground of activity, anti-corruption legislation, regional anti-corruption policy, public service, state policy, corruption prevention, anti-corruption policy, corruption.

$\mathrm{Y}$ казом Президента Российской Федерации от 15 июля 2015 года № 364 «0 мерах по совершенствованию организации деятельности в области противодействия коррупции» [1] (далее по тексту - Указ), целью которого явилось обеспечение единой государственной политики в области противодействия коррупции, утверждено Типовое положение (далее по тексту - Типовое положение) 


\section{Административное и муниципальное право 7 (103) 2016}

о комиссии по координации работы по противодействию коррупции в субъекте Российской Федерации (далее по тексту - Комиссия).

Издание этого указа было предопределено ещё Национальным планом противодействия коррупции на 2014 - 2015 годы, утверждённым Указом Президента Российской Федерации от 11 апреля 2014 г. № 226 [2], в котором Правительству Российской Федерации, президиуму Совета при Президенте Российской Федерации по противодействию коррупции было предписано разработать и представить в установленном порядке проект типового положения о комиссиях по координации работы по противодействию коррупции в субъектах Российской Федерации.

Согласно пункту 1 Указа Комиссия является постоянно действующим координационным органом при высшем должностном лице (руководителе высшего исполнительного органа государственной власти) субъекта Российской Федерации.

Формирование такой Комиссии, кроме того, предусмотрено частью 5 статьи 5 Федерального закона от 25 декабря 2008 г. № 273-ФЗ «0 противодействии коррупции» [3], согласно которой в целях обеспечения координации деятельности федеральных органов исполнительной власти, органов исполнительной власти субъектов Российской Федерации и органов местного самоуправления по реализации государственной политики в области противодействия коррупции по решению Президента Российской Федерации могут формироваться органы в составе представителей федеральных органов государственной власти, органов государственной власти субъектов Российской Федерации и иных лиц.

На федеральном уровне таким органом является Совет при Президенте Российской Федерации по противодействию коррупции, созданный на основании Указа Президента Российской Федерации от 19 мая 2008 г. № 815 «0 мерах по противодействию коррупции» [4].

В субъектах Российской Федерации также были созданы соответствующие Советы, в некоторых субъектах, таких как Республика Татарстан, даже с опережением федерального законодательства. Так, в республике 18 августа 2006 года Указом Президента Республики Татарстан был образован Республиканский совет по реализации антикоррупционной политики [5], который 21 февраля 2011 года Указом Президента РТ от 21 февраля 2011 г. № УП-71 «О Совете при Президенте Республики Татарстан по противодействию коррупции» [6] был переименован в Совет при Президенте Республики Татарстан по противодействию коррупции.

В связи с изданием Указа Президента Российской Федерации от 15 июля 2015 года № 364 «0 мерах по совершенствованию организации деятельности в области противодействия коррупции», Указом Президента Республики Татарстан от 13 октября 2015 г. № УП-986 «О Комиссии по координации работы по противодействию коррупции в Республике Татарстан» [7] Совет при Президенте Республики Татарстан по противодействию коррупции преобразован в Комиссию по координации работы по противодействию коррупции в Республике Татарстан. Этим же Указом упразднена Комиссия по соблюдению требований к должностному поведению лиц, замещающих государственные должности Республики Татарстан, и урегулированию конфликта интересов и осуществление её функций, возложено на Комиссию по координации работы по противодействию коррупции в Республике Татарстан.

«Её (комиссии) первоочередная задача - обеспечение исполнения решений Совета при Президенте России по противодействию коррупции и его президиума, - отметил Президент РТ. - Таким образом, можно сделать вывод о стандартизации и установлении определённой вертикали в системе противодействия коррупции на всей территории России» [8].

Пункт 2 Типового положения определяет правовую основу деятельности комиссии по координации работы по противодействию коррупции в субъекте Российской Федерации, её источники. К таким источникам относятся Конституция Российской Федерации, федеральные конституционные законы, федеральные законы, указы и распоряжения Президента Российской Федерации, постановления и распоряжения Правительства Российской Федерации, иные нормативные правовые акты Российской Федерации, а также положение о комиссии.

Неслучайно указанный пункт на первом месте среди нормативных актов, на основании которых осуществляется деятельность Комиссии, называет Конституцию Российской Федерации. Конституция Российской Федерации имеет высшую юридическую силу, прямое действие и применяется на всей территории Российской Федерации. Законы и иные правовые акты, принимаемые в Российской Федерации, не должны противоречить Конституции Российской Федерации (часть 1 статьи 15 Конституции Российской Федерации).

В соответствии с этим конституционным положением, Верховный Суд Российской Федерации в своём Постановлении Пленума от 31 октября 1995 г. № 8 «0 некоторых вопросах применения судами Конституции Российской Федерации при осуществлении правосудия» [9] предписывает судам при рассмотрении дел следует оценивать содержание закона или иного нормативного правового акта, 
регулирующего рассматриваемые судом правоотношения, и во всех необходимых случаях применять Конституцию Российской Федерации в качестве акта прямого действия.

Суд, разрешая дело, применяет непосредственно Конституцию, в частности:

а) когда закрепленные нормой Конституции положения, исходя из её смысла, не требуют дополнительной регламентации и не содержат указания на возможность её применения при условии принятия федерального закона, регулирующего права, свободы, обязанности человека и гражданина и другие положения;

б) когда Конституционным Судом Российской Федерации выявлен пробел в правовом регулировании либо когда пробел образовался в связи с признанием не соответствующими Конституции нормативного правового акта или его отдельных положений с учетом порядка, сроков и особенностей исполнения решения Конституционного Суда Российской Федерации, если они в нем указаны.

Непосредственно прямое отношение к деятельности Комиссии имеют большинство норм первой и второй глав Конституции России, закрепляющих основы конституционного строя, а также права и свободы человека и гражданина. И это не случайно, так как, в соответствии со статьёй 2 Конституции, «человек, его права и свободы являются высшей ценностью. Признание, соблюдение и защита прав и свобод человека и гражданина обязанность государства». Одной из основных задач Комиссии, несомненно, является защита конституционного строя и прав и свобод человека и гражданина.

Федеральные конституционные законы и федеральные законы.

Следующими после Конституции по юридической силе являются федеральные конституционные законы. Они принимаются по вопросам, непосредственно связанным с Конституцией, и регулируют наиболее важные правовые отношения. За федеральными конституционными законами по юридической силе следуют федеральные законы.

Как определено в статье 76 Конституции Российской Федерации, по предметам ведения Российской Федерации принимаются федеральные конституционные законы и федеральные законы, имеющие прямое действие на всей территории России; по предметам совместного ведения России и её субъектов издаются федеральные законы и принимаемые в соответствии с ними законы и иные нормативные правовые акты субъектов Российской Федерации; федеральные законы не могут противоречить федеральным конституционным законам. Перечень вопросов, находящихся в исключительном ведении России, определён в статье 71, а перечень вопросов, находящихся в совместном ведении России и её субъектов, - в части 1 статьи 72 Конституции Российской Федерации.

Основным «антикоррупционным» федеральным законом является Федеральный закон от 25 декабря 2008 г. № 273-Ф3 «0 противодействии коррупции». Кроме того, в так называемый «антикоррупционный пакет» входят и федеральные законы «0 контроле за соответствием расходов лиц, замещающих государственные должности, и иных лиц их доходам» [10], «0 запрете отдельным категориям лиц открывать и иметь счета (вклады), хранить наличные денежные средства и ценности в иностранных банках, расположенных за пределами территории Российской Федерации, владеть и (или) пользоваться иностранными финансовыми инструментами» [11]. Одним из немаловажных федеральных законов, которым должна руководствоваться Комиссия, является Федеральный закон от 27 июля 2004 г.№ 79-Ф3 «О государственной гражданской службе Российской Федерации» [12].

Указы и распоряжения Президента Российской Федерации.

Издание указов и распоряжений Президентом Российской Федерации регламентировано статьёй 90 Конституции Российской Федерации. Указы и распоряжения Президента Российской Федерации обязательны для исполнения на всей территории Российской Федерации и не должны противоречить Конституции Российской Федерации и федеральным законам.

Часть первая статьи 5 Федерального закона от 25 декабря 2008 г. № 273-Ф3 «0 противодействии коррупции» определяет вопросы, по которым Президент издаёт указы и распоряжения. Так, указанной статьёй предусмотрено, что Президент Российской Федерации: 1) определяет основные направления государственной политики в области противодействия коррупции; 2) устанавливает компетенцию федеральных органов исполнительной власти, руководство деятельностью которых он осуществляет, в области противодействия коррупции.

Среди указов Президента Российской Федерации, составляющих правовую основу деятельности Комиссии, следует назвать следующие: непосредственно указ, утверждающий Типовое Положение, Указ Президента Российской Федерации от 19 мая 2008 г. № 815 «0 мерах по противодействию коррупции» [4], Указ Президента Российской Федерации от 25 февраля 2011 г.№ 233 «0 некоторых вопросах организации деятельности президиума Совета при Президенте Российской Федерации по противодействию коррупции» [13], Указ Президента Российской Федерации от 


\section{Административное и муниципальное право 7 (103) • 2016}

08 июля 2013 г.№ 613 «Вопросы противодействия коррупции» [14], Указ Президента Российской Федерации от 03.12.2013 № 878 «Об Управлении Президента Российской Федерации по вопросам противодействия коррупции» [15], Указ Президента Российской Федерации от 14 февраля 2014 г.№ 80 «О некоторых вопросах организации деятельности по противодействию коррупции» [16], Указ Президента Российской Федерации от 11 апреля 2014 г.№ 226 «0 Национальном плане противодействия коррупции на 2014 - 2015 годы» [2], Указ Президента Российской Федерации от 08 марта 2015 г.№ 120 «0 некоторых вопросах противодействия коррупции» [17] и др.

Постановления и распоряжения Правительства Российской Федерации.

Согласно статьи 115 Конституции Российской Федерации, на основании и во исполнение Конституции Российской Федерации, федеральных законов, нормативных указов Президента Российской Федерации Правительство Российской Федерации издаёт постановления и распоряжения, обеспечивает их исполнение. Постановления и распоряжения Правительства Российской Федерации обязательны к исполнению в Российской Федерации и в случае их противоречия Конституции Российской Федерации, федеральным законам и указам Президента Российской Федерации могут быть отменены Президентом Российской Федерации.

Согласно части 3 статьи 5 Федерального закона от 25 декабря 2008 г. № 273-Ф3 «0 противодействии коррупции» Правительство Российской Федерации распределяет функции между федеральными органами исполнительной власти, руководство деятельностью которых оно осуществляет, по противодействию коррупции. Соответственно для решения обозначенных указанным выше законом задач (и не только) Правительство и издаёт соответствующие постановления и распоряжения. Примерами постановлений Правительства Российской Федерации, составляющими правовую основу деятельности Комиссии служат следующие: Постановление Правительства Российской Федерации от 05 июля 2013 г.№ 568 «0 распространении на отдельные категории граждан ограничений, запретов и обязанностей, установленных Федеральным законом «0 противодействии коррупции» и другими федеральными законами в целях противодействия коррупции» [18], Постановление Правительства Российской Федерации от 18 декабря 2014 г.№ 1405 «О некоторых вопросах противодействия коррупции» [19] и др.

Иные нормативные правовые акты Российской Федерации.

К иным нормативным правовым актам Российской Федерации относятся нормативные правовые акты иных федеральных органов государственной власти федеральных органов государственной власти, нормативные правовые акты органов государственной власти субъектов Российской Федерации, а также муниципальные правовые акты. Поскольку Комиссия - это орган при высшем должностном лице субъекта Российской Федерации, то нормативные правовые акты иных федеральных органов государственной власти, а тем более муниципальные правовые акты вряд ли будут составлять правовую основу её деятельности. Правовую основу деятельности Комиссии на этом уровне будут составлять нормативные правовые акты органов государственной власти субъектов Российской Федерации.

Законы и иные нормативные правовые акты субъектов Российской Федерации в соответствии статьёй 76 Конституции Российской Федерации принимаются по предметам совместного ведения России и её субъектов, а также вне пределов ведения России, совместного ведения России и её субъектов.

Перечень вопросов, которые регулируются законами субъектов Российской Федерации, определён в статье 5 Федерального закона от 06 октября 1999 г. № 184-Ф3 «Об общих принципах организации законодательных (представительных) и исполнительных органов государственной власти субъектов Российской Федерации» [20].

Другими нормативно-правовыми актами субъектов Российской Федерации, которые представляют интерес в рамках настоящего исследования, являются нормативные правовые акты высших должностных лиц субъектов Российской Федерации (руководителей высших исполнительных органов государственной власти субъектов Российской Федерации), высших исполнительных органов государственной власти субъектов Российской Федерации.

Согласно статье 22 Федерального закона от 06 октября 1999 г.№ 184-Ф3 «Об общих принципах организации законодательных (представительных) и исполнительных органов государственной власти субъектов Российской Федерации» высшее должностное лицо субъекта Российской Федерации (руководитель высшего исполнительного органа государственной власти субъекта Российской Федерации) на основании и во исполнение Конституции Российской Федерации, федеральных законов, нормативных актов Президента Российской Федерации, постановлений Правительства Российской Федерации, конституции (устава) и законов субъекта Российской Федерации издаёт указы (постановления) и распоряжения, которые обязательны к исполнению в субъекте Российской Федерации и не должны противоречить Конституции Российской Федерации, федеральным зако- 
нам, принятым по предметам ведения Российской Федерации и предметам совместного ведения Российской Федерации и субъектов Российской Федерации, указам Президента Российской Федерации, постановлениям Правительства Российской Федерации, конституции (уставу) и законам субъекта Российской Федерации.

К примеру, нормативно правовыми актами органов государственной власти Республики Татарстан, составляющими правовую основу деятельности республиканской комиссии, являются следующие: Закон Республики Татарстан от 04 мая 2006 г.№ 34-3РТ «0 противодействии коррупции в Республике Татарстан» [21], Указ Президента Республики Татарстан от 13 октября 2015 г.№ УП-986 «О Комиссии по координации работы по противодействию коррупции в Республике Татарстан», Указ Президента Республики Татарстан от 06 ноября 2013 г.№ УП-1084 «0 мерах по реализации отдельных положений Федерального закона «0 противодействии коррупции» и Федерального закона «О контроле за соответствием расходов лиц, замещающих государственные должности, и иных лиц их доходам» и о внесении изменений в отдельные указы Президента Республики Татарстан по вопросам противодействия коррупции» [22] и др.

Следующим нормативным правовым актом, определяющим правовую основу деятельности Комиссии является само Типовое положение. Указанное положение определяет правовой статус Комиссии, правовую основу её деятельности, основные задачи, полномочия, порядок её формирования, а также организацию деятельности Комиссии и порядок её работы.

Согласно пункту 3 Типового положения Комиссия осуществляет свою деятельность во взаимодействии с Управлением Президента Российской Федерации по вопросам противодействия коррупции.

Управление Президента Российской Федерации по вопросам противодействия коррупции образовано в целях обеспечения деятельности Президента Российской Федерации по реализации государственной политики в области противодействия коррупции в составе Администрации Президента Российской Федерации.

Основными задачами Управления Президента Российской Федерации по вопросам противодействия коррупции являются:

1) участие в обеспечении реализации Президентом Российской Федерации его полномочий по проведению государственной политики в области противодействия коррупции;

2) осуществление в пределах своей компетенции контроля за исполнением федеральных конституционных законов, федеральных законов (в части, касающейся полномочий Президента Российской Федерации), указов, распоряжений, поручений и указаний Президента Российской Федерации по вопросам противодействия коррупции;

3) подготовка предложений Президенту Российской Федерации по вопросам противодействия коррупции в органах государственной власти, иных государственных органах, органах местного самоуправления и организациях, а также урегулирования конфликта интересов;

4) содействие Президенту Российской Федерации в пределах своей компетенции в обеспечении согласованного функционирования и взаимодействия органов государственной власти, иных государственных органов, органов местного самоуправления и организаций по вопросам противодействия коррупции;

5) обеспечение деятельности Совета при Президенте Российской Федерации по противодействию коррупции и президиума этого Coвета, Комиссии по соблюдению требований к служебному поведению федеральных государственных служащих Администрации Президента Российской Федерации и урегулированию конфликта интересов, а также в пределах своей компетенции - деятельности иных совещательных и консультативных органов при Президенте Российской Федерации;

6) обеспечение взаимодействия Президента Российской Федерации и Руководителя Администрации Президента Российской Федерации с полномочными представителями Президента Российской Федерации в федеральных округах по вопросам, относящимся к компетенции Управления.

К сожалении ни в Положении об Управлении Президента Российской Федерации по вопросам противодействия коррупции, ни в Типовом положении не определён порядок, формы взаимодействия Управления Президента Российской Федерации по вопросам противодействия коррупции и Комиссии. Определение такого порядка способствовало бы более эффективному выполнению обоими ведомствами возложенных на них задач.

Пункт 4 Типового положения устанавливает, что Комиссия выполняет функции, возложенные на комиссию по соблюдению требований к служебному (должностному) поведению и урегулированию конфликта интересов в отношении лиц, замещающих государственные должности субъекта Российской Федерации, для которых федеральными законами не предусмотрено иное, и рассматривает соответствующие вопросы в порядке, определенном нормативным правовым актом субъекта Российской Федерации. 


\section{Административное и муниципальное право 7 (103) 2016}

В соответствии со статьёй 10 Федерального закона от 25 декабря 2008 г. № 273-ФЗ «О противодействии коррупции» под конфликтом интересов понимается ситуация, при которой личная заинтересованность (прямая или косвенная) лица, замещающего должность, замещение которой предусматривает обязанность принимать меры по предотвращению и урегулированию конфликта интересов, влияет или может повлиять на надлежащее, объективное и беспристрастное исполнение им должностных (служебных) обязанностей (осуществление полномочий).

По Информации Минтруда России от 19 октября 2012 г. «Обзор типовых ситуаций конфликта интересов на государственной службе Российской Федерации и порядка их урегулирования» [23] под определение «конфликт интересов» попадает множество конкретных ситуаций, в которых государственный служащий может оказаться в процессе исполнения должностных обязанностей. Учитывая разнообразие частных интересов государственных служащих, составить исчерпывающий перечень таких ситуаций не представляется возможным. Тем не менее, можно выделить ряд ключевых «областей регулирования», в которых возникновение конфликта интересов является наиболее вероятным:

- выполнение отдельных функций государственного управления в отношении родственников и/или иных лиц, с которыми связана личная заинтересованность государственного служащего;

- выполнение иной оплачиваемой работы;

- владение ценными бумагами, банковскими вкладами;

- получение подарков и услуг;

- имущественные обязательства и судебные разбирательства;

- взаимодействие с бывшим работодателем и трудоустройство после увольнения с государственной службы;

- явное нарушение установленных запретов (например, использование служебной информации, получение наград, почетных и специальных званий (за исключением научных) от иностранных государств и др.).

Наряду с определением конфликта интересов на государственной или муниципальной службе Федерального закона «О противодействии коррупции» использует термин «личная заинтересованность», определение которого даёт в части 2 статьи 10. Так под личной заинтересованностью понимается возможность получения государственным или муниципальным служащим при исполнении им должностных обязанностей, доходов в виде денег, ценностей, иного имущества или услуг имущественного характера, иных имущественных прав для себя или для третьих лиц.

В статье 11 Федерального закона «0 противодействии коррупции» закреплён порядок предотвращения и урегулирования конфликта интересов на государственной и муниципальной службе.

Создание комиссий по соблюдению требований к служебному поведению государственных или муниципальных служащих и урегулированию конфликта интересов предопределено статьёй 12 указанного выше закона.

Указом Президента Российской Федерации от 1 июля 2010 г. № 821 «0 комиссиях по соблюдению требований к служебному поведению федеральных государственных служащих и урегулированию конфликта интересов» [24], в соответствии с Федеральным законом от 25 декабря 2008 г. № 273-Ф3 «0 противодействии коррупции» было утверждено положение о комиссиях по соблюдению требований к служебному поведению федеральных государственных служащих и урегулированию конфликта интересов.

Основной задачей комиссий, согласно вышеупомянутому Указу, является содействие государственным органам в обеспечении соблюдения федеральными государственными служащими ограничений и запретов, требований о предотвращении или урегулировании конфликта интересов, а также в обеспечении исполнения ими обязанностей, установленных Федеральным законом от 25 декабря 2008 г. № 273-Ф3 «0 противодействии коррупции», другими федеральными законами; в осуществлении в государственном органе мер по предупреждению коррупции.

Вопросы, касающиеся соблюдения требований к служебному (должностному) поведению лиц, замещающих государственные должности Российской Федерации и отдельные должности федеральной государственной службы, и урегулирования конфликта интересов, рассматриваются президиумом Совета при Президенте Российской Федерации по противодействию коррупции [25].

В субъектах Российской Федерации, в частности в Республике Татарстан Указом Президента Республики Татарстан была создана Комиссия по соблюдению требований к должностному поведению лиц, замещающих государственные должности Республики Татарстан, и урегулированию конфликта интересов Комиссии по соблюдению требований к должностному поведению лиц, замещающих государственные должности Республики Татарстан, и урегулированию конфликта интересов.

В связи с изданием Указа Президента Российской Федерации от 15 июля 2015 года № 364 «0 мерах по совершенствованию организации деятельности в области противодействия коррупции», как 
уже отмечалось выше, Указом Президента Республики Татарстан от 13 октября 2015 г. № УП-986 «0 Комиссии по координации работы по противодействию коррупции в Республике Татарстан», комиссия по соблюдению требований к должностному поведению лиц, замещающих государственные должности Республики Татарстан, и урегулированию конфликта интересов была упразднена и её функции были возложены на Комиссию по координации работы по противодействию коррупции в Республике Татарстан. Этим же Указом было утверждено Положение о порядке рассмотрения Комиссией по координации работы по противодействию коррупции в Республике Татарстан вопросов, касающихся соблюдения требований к должностному поведению лиц, замещающих государственные должности Республики Татарстан, и урегулирования конфликта интересов.

\section{Библиография:}

1. О мерах по совершенствованию организации деятельности в области противодействия коррупции: указ Президента Российской Федерации от 15 июля 2015 года № 364 // Собрание законодательства Российской Федерации. - 2015.-№ 29 (часть II). - Ст. 4477.

2. $\quad$ О Национальном плане противодействия коррупции на 2014 - 2015 годы: указ Президента Российской Федерации от 11 апреля 2014 г. № 226 // Собрание законодательства Российской Федерации. - 2014. - № 15. - Ст. 1729.

3. О противодействии коррупции: федер. закон от 25 декабря 2008 г. № 273-Ф3 // Собрание законодательства Российской Федерации. - 2008. - № 52 (ч. 1). - Ст. 6228.

4. О мерах по противодействию коррупции: указ Президента Российской Федерации от 19 мая 2008 г. № 815 // Собрание законодательства Российской Федерации. - 2008. - № 21. - Ст. 2429.

5. О Республиканском совете по реализации антикоррупционной политики: указ Президента Республики Татарстан от 18 августа 2006 г. № УП-315 // Сборник постановлений и распоряжений Кабинета Министров Республики Татарстан и нормативных актов республиканских органов исполнительной власти. - 2006. - № 32. Ст. 0870.

6. $\quad$ О Совете при Президенте Республики Татарстан по противодействию коррупции: указ Президента Республики Татарстан от 21 февраля 2011 г. № УП-71 // Сборник постановлений и распоряжений Кабинета Министров Республики Татарстан и нормативных актов республиканских органов исполнительной власти. - 2001. - № 13.

7. $\quad$ К Комиссии по координации работы по противодействию коррупции в Республике Татарстан: указ Президента Республики Татарстан от 13 октября 2015 г.№ УП-986 «» // Сборник постановлений и распоряжений Кабинета Министров Республики Татарстан и нормативных актов республиканских органов исполнительной власти. 2015. - № 78. - Ст. 2688.

8. Из выступления Президента Республики Татарстан на первом заседании Комиссии по координации работы по противодействию коррупции в Республике Татарстан // http://vlast16.ru/81252.

9. О некоторых вопросах применения судами Конституции Российской Федерации при осуществлении правосудия: постановление Пленума Верховного Суда Российской Федерации от 31 октября 1995 г. № 8 // Бюллетень Верховного Суда Российской Федерации. - 1996. - № 1.

10. О контроле за соответствием расходов лиц, замещающих государственные должности, и иных лиц их доходам: федер. закон от 03.12.2012 г. № 230-Ф3 // Собрание законодательства Российской Федерации. - 2012. - № 50 (часть 4). - Ст. 6953.

11. О запрете отдельным категориям лиц открывать и иметь счета (вклады), хранить наличные денежные средства и ценности в иностранных банках, расположенных за пределами территории Российской Федерации, владеть и (или) пользоваться иностранными финансовыми инструментами: федер. закон от 07 мая 2013 г.№ 79-Ф3 // Собрание законодательства Российской Федерации. - 2013. - № 19. - Ст. 2306.

12. О государственной гражданской службе Российской Федерации: федер. закон от 27 июля 2004 г.№ 79 -Ф3 // Собрание законодательства Российской Федерации. - 2004. - № 31. - Ст. 3215.

13. О некоторых вопросах организации деятельности президиума Совета при Президенте Российской Федерации по противодействию коррупции: указ Президента Российской Федерации от 25 февраля 2011 г. № 233 // Собрание законодательства Российской Федерации. - 2011.- № 9. - Ст. 1223.

14. Вопросы противодействия коррупции: указ Президента Российской Федерации от 08 июля 2013 г.№ 613 // Собрание законодательства Российской Федерации. - 2013.- № 28.- Ст. 3813.

15. Об Управлении Президента Российской Федерации по вопросам противодействия коррупции: указ Президента Российской Федерации от 03.12.2013 № 878 // Собрание законодательства Российской Федерации. - 2013. № 49 (часть VII).- Ст. 6399.

16. О некоторых вопросах организации деятельности по противодействию коррупции: указ Президента Российской Федерации от 14 февраля 2014 г. № 80 // Собрание законодательства Российской Федерации. - 2014.№ 7.- Ст. 672.

17. О некоторых вопросах противодействия коррупции: указ Президента Российской Федерации от 08 марта 2015 г. № 120 // Собрание законодательства Российской Федерации. - 2015.- № 10.- Ст. 1506.

18. О распространении на отдельные категории граждан ограничений, запретов и обязанностей, установленных Федеральным законом «0 противодействии коррупции» и другими федеральными законами в целях противодействия коррупции: постановление Правительства Российской Федерации от 05 июля 2013 г.№ 568 // Собрание законодательства Российской Федерации. - 2013. - № 28.- Ст. 3833. 


\section{Административное и муниципальное право 7 (103) • 2016}

19. О некоторых вопросах противодействия коррупции: постановление Правительства Российской Федерации от 18 декабря 2014 г.№ 1405 // Собрание законодательства Российской Федерации. - 2014. - № 52 (часть I). Ст. 7782.

20. Об общих принципах организации законодательных (представительных) и исполнительных органов государственной власти субъектов Российской Федерации: федер. закон от 06 октября 1999 г. № 184-Ф3 // Собрание законодательства Российской Федерации. - 1999. - № 42.- Ст. 5005.

21. О противодействии коррупции в Республике Татарстан: закон Республики Татарстан от 04 мая 2006 г. № 34-3РТ // Республика Татарстан. - 2006. - 7 мая.

22. О мерах по реализации отдельных положений Федерального закона «0 противодействии коррупции» и Федерального закона «0 контроле за соответствием расходов лиц, замещающих государственные должности, и иных лиц их доходам» и о внесении изменений в отдельные указы Президента Республики Татарстан по вопросам противодействия коррупции: указ Президента Республики Татарстан от 06 ноября 2013 г.№ УП-1084 // Республика Татарстан. - 2013. - 9 нояб.

23. Обзор типовых ситуаций конфликта интересов на государственной службе Российской Федерации и порядка их урегулирования: информация Минтруда России от 19 октября 2012 г. // Официально указанный документ опубликован не был [Электронный ресурс] // Электрон. текст. дан. - Доступ из справ.-правовой системы «Консультант Плюс».

24. О комиссиях по соблюдению требований к служебному поведению федеральных государственных служащих и урегулированию конфликта интересов: указ Президента Российской Федерации от 1 июля 2010 г. № 821 // Собрание законодательства Российской Федерации. - 2010. - № 27. - Ст. 3446.

25. О некоторых вопросах организации деятельности президиума Совета при Президенте Российской Федерации по противодействию коррупции: указ Президента Российской Федерации от 25 февраля 2011 г. № 233 // Собрание законодательства Российской Федерации. - 2011. - № 9. - Ст. 1223.

\section{References (transliterated):}

1. 0 merakh po sovershenstvovaniyu organizatsii deyatel'nosti v oblasti protivodeistviya korruptsii: ukaz Prezidenta Rossiiskoi Federatsii ot 15 iyulya 2015 goda № 364 // Sobranie zakonodatel'stva Rossiiskoi Federatsii. - 2015.-№ 29 (chast' II). - St. 4477.

2. O Natsional'nom plane protivodeistviya korruptsii na 2014 - 2015 gody: ukaz Prezidenta Rossiiskoi Federatsii ot 11 aprelya 2014 g. № 226 // Sobranie zakonodatel'stva Rossiiskoi Federatsii. - 2014. - № 15. - St. 1729.

3. 0 protivodeistvii korruptsii: feder. zakon ot 25 dekabrya 2008 g. № 273-FZ // Sobranie zakonodatel'stva Rossiiskoi Federatsii. - 2008. - № 52 (ch. 1). - St. 6228.

4. 0 merakh po protivodeistviyu korruptsii: ukaz Prezidenta Rossiiskoi Federatsii ot 19 maya 2008 g. № 815 // Sobranie zakonodatel'stva Rossiiskoi Federatsii. - 2008. - № 21. - St. 2429.

5. O Respublikanskom sovete po realizatsii antikorruptsionnoi politiki: ukaz Prezidenta Respubliki Tatarstan ot 18 avgusta 2006 g. № UP-315 // Sbornik postanovlenii i rasporyazhenii Kabineta Ministrov Respubliki Tatarstan i normativnykh aktov respublikanskikh organov ispolnitel'noi vlasti. - 2006. - № 32. - St. 0870.

6. O Sovete pri Prezidente Respubliki Tatarstan po protivodeistviyu korruptsii: ukaz Prezidenta Respubliki Tatarstan ot 21 fevralya 2011 g. № UP-71 // Sbornik postanovlenii i rasporyazhenii Kabineta Ministrov Respubliki Tatarstan i normativnykh aktov respublikanskikh organov ispolnitel'noi vlasti. - 2001. - № 13.

7. O Komissii po koordinatsii raboty po protivodeistviyu korruptsii v Respublike Tatarstan: ukaz Prezidenta Respubliki Tatarstan ot 13 oktyabrya 2015 g.№ UP-986 «» // Sbornik postanovlenii i rasporyazhenii Kabineta Ministrov Respubliki Tatarstan i normativnykh aktov respublikanskikh organov ispolnitel'noi vlasti. - 2015. - № 78. - St. 2688.

8. Iz vystupleniya Prezidenta Respubliki Tatarstan na pervom zasedanii Komissii po koordinatsii raboty po protivodeistviyu korruptsii v Respublike Tatarstan // http://vlast16.ru/81252.

9. 0 nekotorykh voprosakh primeneniya sudami Konstitutsii Rossiiskoi Federatsii pri osushchestvlenii pravosudiya: postanovlenie Plenuma Verkhovnogo Suda Rossiiskoi Federatsii ot 31 oktyabrya 1995 g. № 8 // Byulleten' Verkhovnogo Suda Rossiiskoi Federatsii. - 1996. - № 1.

10. O kontrole za sootvetstviem raskhodov lits, zameshchayushchikh gosudarstvennye dolzhnosti, i inykh lits ikh dokhodam: feder. zakon ot 03.12.2012 g. № 230-FZ // Sobranie zakonodatel'stva Rossiiskoi Federatsii. - 2012. - № 50 (chast' 4). - St. 6953.

11. O zaprete otdel'nym kategoriyam lits otkryvat' i imet' scheta (vklady), khranit' nalichnye denezhnye sredstva i tsennosti v inostrannykh bankakh, raspolozhennykh za predelami territorii Rossiiskoi Federatsii, vladet' i (ili) pol'zovat'sya inostrannymi finansovymi instrumentami: feder. zakon ot 07 maya 2013 g.№ 79-FZ // Sobranie zakonodatel'stva Rossiiskoi Federatsii. - 2013. - № 19. - St. 2306.

12. O gosudarstvennoi grazhdanskoi sluzhbe Rossiiskoi Federatsii: feder. zakon ot 27 iyulya 2004 g.№ 79-FZ // Sobranie zakonodatel'stva Rossiiskoi Federatsii. - 2004. - № 31. - St. 3215.

13. O nekotorykh voprosakh organizatsii deyatel'nosti prezidiuma Soveta pri Prezidente Rossiiskoi Federatsii po protivodeistviyu korruptsii: ukaz Prezidenta Rossiiskoi Federatsii ot 25 fevralya 2011 g. № 233 // Sobranie zakonodatel'stva Rossiiskoi Federatsii. - 2011.- № 9. - St. 1223.

14. Voprosy protivodeistviya korruptsii: ukaz Prezidenta Rossiiskoi Federatsii ot 08 iyulya 2013 g.№ 613 // Sobranie zakonodatel'stva Rossiiskoi Federatsii. - 2013.- № 28.- St. 3813.

15. Ob Upravlenii Prezidenta Rossiiskoi Federatsii po voprosam protivodeistviya korruptsii: ukaz Prezidenta Rossiiskoi Federatsii ot 03.12.2013 № 878 // Sobranie zakonodatel'stva Rossiiskoi Federatsii. - 2013. - № 49 (chast' VII).- St. 6399. 
16. O nekotorykh voprosakh organizatsii deyatel'nosti po protivodeistviyu korruptsii: ukaz Prezidenta Rossiiskoi Federatsii ot 14 fevralya 2014 g. № 80 // Sobranie zakonodatel'stva Rossiiskoi Federatsii. - 2014.- № 7.- St. 672.

17. O nekotorykh voprosakh protivodeistviya korruptsii: ukaz Prezidenta Rossiiskoi Federatsii ot 08 marta 2015 g.№ 120 // Sobranie zakonodatel'stva Rossiiskoi Federatsii. - 2015.- № 10.- St. 1506.

18. O rasprostranenii na otdel'nye kategorii grazhdan ogranichenii, zapretov i obyazannostei, ustanovlennykh Federal'nym zakonom «O protivodeistvii korruptsii» i drugimi federal'nymi zakonami v tselyakh protivodeistviya korruptsii: postanovlenie Pravitel'stva Rossiiskoi Federatsii ot 05 iyulya 2013 g.№ 568 // Sobranie zakonodatel'stva Rossiiskoi Federatsii. - 2013. - № 28.- St. 3833.

19. O nekotorykh voprosakh protivodeistviya korruptsii: postanovlenie Pravitel'stva Rossiiskoi Federatsii ot 18 dekabrya 2014 g.№ 1405 // Sobranie zakonodatel'stva Rossiiskoi Federatsii. - 2014. - № 52 (chast' I). - St. 7782.

20. Ob obshchikh printsipakh organizatsii zakonodatel'nykh (predstavitel'nykh) i ispolnitel'nykh organov gosudarstvennoi vlasti sub"ektov Rossiiskoi Federatsii: feder. zakon ot 06 oktyabrya 1999 g. № 184-FZ // Sobranie zakonodatel'stva Rossiiskoi Federatsii. - 1999. - № 42.- St. 5005.

21. O protivodeistvii korruptsii v Respublike Tatarstan: zakon Respubliki Tatarstan ot 04 maya 2006 g. № 34-ZRT // Respublika Tatarstan. - 2006. - 7 maya.

22. O merakh po realizatsii otdel'nykh polozhenii Federal'nogo zakona «0 protivodeistvii korruptsii» i Federal'nogo zakona «O kontrole za sootvetstviem raskhodov lits, zameshchayushchikh gosudarstvennye dolzhnosti, i inykh lits ikh dokhodam» i o vnesenii izmenenii v otdel'nye ukazy Prezidenta Respubliki Tatarstan po voprosam protivodeistviya korruptsii: ukaz Prezidenta Respubliki Tatarstan ot 06 noyabrya 2013 g.№ UP-1084 // Respublika Tatarstan. - 2013. - 9 noyab.

23. Obzor tipovykh situatsii konflikta interesov na gosudarstvennoi sluzhbe Rossiiskoi Federatsii i poryadka ikh uregulirovaniya: informatsiya Mintruda Rossii ot 19 oktyabrya 2012 g. // Ofitsial'no ukazannyi dokument opublikovan ne byl [Elektronnyi resurs] // Elektron. tekst. dan. - Dostup iz sprav.-pravovoi sistemy «Konsul'tant Plyus».

24. O komissiyakh po soblyudeniyu trebovanii k sluzhebnomu povedeniyu federal'nykh gosudarstvennykh sluzhashchikh i uregulirovaniyu konflikta interesov: ukaz Prezidenta Rossiiskoi Federatsii ot 1 iyulya 2010 g. № 821 // Sobranie zakonodatel'stva Rossiiskoi Federatsii. - 2010. - № 27. - St. 3446.

25. O nekotorykh voprosakh organizatsii deyatel'nosti prezidiuma Soveta pri Prezidente Rossiiskoi Federatsii po protivodeistviyu korruptsii: ukaz Prezidenta Rossiiskoi Federatsii ot 25 fevralya 2011 g. № 233 // Sobranie zakonodatel'stva Rossiiskoi Federatsii. - 2011. - № 9. - St. 1223. 